\title{
An Online Survey of Consumers of Maharashtra Concerning the Expected Change in the Meat and Meat Product Business
}

\author{
R.N. Waghamare ${ }^{1 *}$, H.K. Popalghat ${ }^{1}$, S.V. Londhe ${ }^{2}$, V.V. Deshmukh ${ }^{1}$ and V.V. Khobe ${ }^{1}$ \\ ${ }^{1}$ Department of Veterinary Public Health and Epidemiology, College of Veterinary and Animal Sciences, Parbhani, INDIA \\ ${ }^{2}$ Department of Livestock Product Technology, College of Veterinary and Animal Sciences, Parbhani, INDIA
}

"Corresponding author: RN Waghamare; E-mail: rupeshwaghmare@gmail.com

Received: 02 Nov., 2021

Revised: 24 Nov., 2021

Accepted: 02 Feb., 2021

\begin{abstract}
The present study was conducted to understand non-vegetarian consumer behavior, preferences, hygienic considerations and their expected changes in meat selling business. A questionnaire in Marathi language was designed with Google form for this online survey. Under these 194 (172 Male and 21 Female) respondents from all regions of Maharashtra state were surveyed. The study revealed that majority of consumers $(90.21 \%)$ preferred hot, freshly slaughtered chicken meat (77.32\%) which include all body parts of the carcass $(56.19 \%)$ and them $(70.62 \%)$ usually preferred to eat non-vegetarian food once or twice in a week. About $68.59 \%$ consumers preferred skinless chicken carcass slaughtered by any ritual method (53.76\%). The study indicates that most of the consumers ( $70.62 \%$ ) usually buy meat from the meat shop near to their residence and nearly $42.78 \%$ consumers showed concern about cleanliness and hygienic condition of the meat selling shop where from they buy non-veg products. Most of the consumers $(82.38 \%)$ ) showed their willingness to purchase home delivery of minimal handled hygienic meat and for this they $(86.17 \%)$ are ready to pay a slightly higher price. It indicates consumer concern about safety of food, but surprisingly, they are unaware of the food laws, quality guidelines, food safety standard. Almost all consumers (96.89\%) agreed that there is a need to raise awareness and to educate consumers regarding this issue.
\end{abstract}

\section{HIGHLIGHTS}

(0 The Maharashtrian consumers usually preferred freshly slaughtered chicken meat.

(0 Consumers are concerned about safety of non-veg food.

(0) They showed willingness to buy home delivery of machine cut meat.

(0) They are ready to pay slightly higher price for this.

Keywords: Consumer, Online Survey, Meat Safety, Awareness

The Maharashtra is the second-most populated state in India having $112,372,972$ populations according to 2011 census. Herein decade the state of Maharashtra has registered a growth of $15.99 \%$ altogether population. Maharashtra state had $9.29 \%$ of the total population of India (Census of India, 2011). Livestock act as a source of protein in the form of milk, egg and meat. Maharashtra rank $5^{\text {th }}$ in a poultry population taking 74.3 million poultry birds, along with this sheep and goat population were 2.7 million and 10.6 million, which are $7^{\text {th }}$ and $6^{\text {th }}$ largest population in a country respectively (GOI, 2019). According to the registrar general release 2018 survey, state has a 59.8 percentage of non-vegetarian population (Anonymous, 2018). The value of meat products includes beef, mutton, pork, hides, skins produced in the country in the year 2016-17 was ₹ 1,94,454 crores with the second largest contributor of worth i.e. $21.18 \%$ (Central Statistical Organization, 2018).

The state of Maharashtra produced approximately

How to cite this article: Waghamare, R.N., Popalghat, H.K., Londhe, S.V. Deshmukh, V.V. and Khobe, V.V. (2021). An online survey of consumers of Maharashtra concerning the expected change in the meat and meat product business. J. Anim. Res., 11(1): 137-141.

Source of Support: DST, New Delhi; Conflict of Interest: None

(क) 
517.5 thousand metric tons of poultry meat in financial year 2017 (Jaganmohan, 2020). India's meat market is valued nearly $\$ 30$ billion, with an annual growth of 2025 percent. Purchasing meat is a daily activity and entails knowledge and information. Yet, Indian meat market has been unorganized, Lack of cold storage infrastructure, there are no government certified labs to standardize the quality of meat, trouble with the cleanness and handling of the meat, therefore Customers are facing lots of challenges while choosing meat for their eating (Wangdi, 2019). The meat consumers concerning expected changes in meat and meat products business are relatively an under researched topic in Maharashtra. In this situation, a consumer's online survey was conducted to study preferences and expectations of non-veg consumers. The finding, to be gained in this survey will guide the new entrepreneurs involved in the meat processing business to develop products matched with consumers' prospects and to carry out research and developments for economists, market analysts, scholars targeting consumer demands and expectations.

\section{MATERIALS AND METHODS}

Online survey was conducted by using Google form in which questionnaire was prepared in Marathi language containing questions related to meat consumption, awareness of consumers concerning type of meat, meat shop hygiene, meat packaging, etc. Total sample sizes of 194 respondents were taken for the survey from all regions of Maharashtra and therefore denote diversified population. Data obtained through survey form questionnaires were documented in a database formed in MS Excel 2016. The collected data were grouped together and presented in the form of frequencies and percentage.

\section{RESULTS AND DISCUSSION}

\section{Background and source of purchase of meat and meat products}

The background information on Gender, place of residence and source of purchase of meat and meat products by consumers has been depicted in Table 1. It had been observed that among the consumers the majority was Male $(89.12 \%)$. In country food associated household works is finished by females, but still the buying of meat from market handled by males by majority of population within the country (Kiran et al., 2018; Kumar et al., 2014). The advantage of the present study is that the urban and rural consumers were 54.92 and 45.08 percent, respectively which represent a diversified population of the state of Maharashtra (GOI, 2020). Some factors associated with gender, place of residence (Urban or Rural), consumption pattern generally have a consequence on meat consumption preferences (Gossard et al., 2003).The majority of consumers favoured chicken meat $(77.32 \%)$, followed by Mutton (63.41\%) and other kind of meat (19.59\%). The preference and consumption of chicken meat are often considered as a universal phenomenon and chicken meat is greatly accepted by consumers worldwide as compared to the other meat consumption. The rise in chicken meat consumption could be due to the versatility of the meat, relatively low cost compare to other meat, the acceptance of the chicken meat to all or any religions and increase in the household income (Kiran et al., 2014; Mohana et al., 2014). Similar finding has been reported by many scholars (Kiran et al., 2018; Karthikeyan et al. 2013). The majority of consumers responded that they usually consume nonveg diet 1 to 2 times a week $(70.62 \%)$ and the rest of the consumers $(29.96 \%)$ like to consume 3 to 4 times a week. Almost $71.26 \%$ of the consumers usually preferred to purchase from known shops only, where they frequent to get the meat and the majority of consumers $(70.62 \%)$ has mentioned this meat shops are located at less than $1 \mathrm{~km}$ distance from their residence. This constitutes one way of ensuring the quality of meat.

Food safety is a scientific discipline describing handling, preparation and storage of food in ways that prevent foodborne illness. Food safety has emerged as a very important global issue with international trade and public health implications. So as to make sure that the food sectors match up to the best global standards, the Government of India enacted an integrated food law called the Food Safety and Standards Act in August 2006 under this law Food Safety and Standards Authority of India was established which is that the regulating body associated with food safety and laying down of standards of food in India (http://www.fssai.gov.in/). These authorities set standards and license the manufacture of food products which are healthy and safe. A current survey revealed that nearly $85.49 \%$ (No + Don't Know) consumers were unaware about whether the meat selling shops where since they buy non veg products registered with FSSAI or not 
and about $47.42 \%$ consumers said this meat selling shops stink and smells bad. Within the present study, about half $(42.78 \%)$ consumers weren't satisfied with the hygienic conditions and cleaning practices adapted by meat shops.

Table 1: Respondent background and Source of Purchase of Meat and meat products

\begin{tabular}{lll}
\hline Question & Options & Result \\
\hline Sex & Male & $172(89.12 \%)$ \\
& Female & $21(10.88 \%)$ \\
\hline Place of residence & Urban & $106(54.92 \%)$ \\
& Rural & $87(45.08 \%)$ \\
\hline & Other & $4(2.06 \%)$ \\
& Chicken & $63(32.47 \%)$ \\
& Chicken \& & $4(2.06 \%)$ \\
& Other & \\
$\begin{array}{l}\text { What type of non-veg do you } \\
\text { usually eat? }\end{array}$ & Chicken \& & $54(27.84 \%)$ \\
& Mutton & \\
& Chicken, Mutton & $29(14.95 \%)$ \\
& Mutton & $39(20.10 \%)$ \\
\hline $\begin{array}{l}\text { How frequently do you eat non } \\
\text { veg in a week? }\end{array}$ & Mutton \& Other 2 times & $137(0.52 \%)$ \\
\hline $\begin{array}{l}\text { How far from your place is the } \\
\text { meat shop located? }\end{array}$ & Less than 1 KM & $137(70.62 \%)$ \\
\hline $\begin{array}{l}\text { Do you buy non veg products } \\
\text { from the same shop regularly? }\end{array}$ & More than 1 KM $57(29.38 \%)$ \\
\hline $\begin{array}{l}\text { Is the cleanliness \& hygiene } \\
\text { maintained to the level of }\end{array}$ & Yes & $55(28.35 \%)$ \\
$\begin{array}{l}\text { satisfaction at the meat shop } \\
\text { where from you buy non veg? }\end{array}$ & Yes & $139(71.65 \%)$ \\
\hline $\begin{array}{l}\text { Does the meat shop where from } \\
\text { you buy non veg stink or smells } \\
\text { bad? }\end{array}$ & No & $83(42.78 \%)$ \\
\hline $\begin{array}{l}\text { Is the meat shop where from you non veg products registered } \\
\text { with FSSAI? }\end{array}$ & Do & $111(57.22 \%)$ \\
\hline & Yes & $102(52.58 \%)$ \\
\hline
\end{tabular}

\section{Consumers Preferences and Consumption pattern}

The non-veg consumption pattern and preferences for non-veg by consumers are given in Table 2. Majority of consumers favoured hot, fresh meat prepared in front of their eye $(90.21 \%)$ rather than frozen or chilled meat $(9.39 \%)$. Parallel finding was testified by various scholars
(Kumar et al., 2014; Singh et al., 2019; Verbeke, 2001). Consumers of the present study showed higher preference to whole carcass i.e. all body parts of carcass collectively $(56.19 \%)$ rather than specific parts $(43.81 \%)$ which could be accredited to cultural habituation. Also, the majority of consumers responded that they usually choose skinless chicken $(68.59 \%)$. Ritual slaughter as the name proposes is based on religious beliefs of a particular religion. Religion as a part of culture impacts consumer attitude and behaviour in general (Pettinger et al., 2004), and food buying decisions and eating behaviours (Mullen et al., 2004). Divergent to the above statement, current data indicated that more than half $(53.76 \%)$ consumers have not influence for ritual slaughter on buying choice.

Table 2: Preferences and Consumption pattern of consumers

\begin{tabular}{|c|c|c|}
\hline Question & Options & Result \\
\hline \multirow[t]{3}{*}{$\begin{array}{l}\text { What is your preference while } \\
\text { buying non veg? }\end{array}$} & $\begin{array}{l}\text { Frozen } \\
\text { Chicken }\end{array}$ & $4(2.06 \%)$ \\
\hline & $\begin{array}{l}\text { Hot Fresh } \\
\text { Meat }\end{array}$ & $175(90.21 \%)$ \\
\hline & $\begin{array}{l}\text { Chilled } \\
\text { Packaged } \\
\text { Meat }\end{array}$ & $15(7.73 \%)$ \\
\hline \multirow[t]{2}{*}{$\begin{array}{l}\text { Do you prefer buying meat parts } \\
\text { separately or to buy it collectively? }\end{array}$} & $\begin{array}{l}\text { All Parts } \\
\text { Collectively }\end{array}$ & $109(56.19 \%)$ \\
\hline & $\begin{array}{l}\text { Specific Part } \\
\text { only }\end{array}$ & $85(43.81 \%)$ \\
\hline \multirow[t]{2}{*}{$\begin{array}{l}\text { What kind of chicken do you } \\
\text { usually prefer? }\end{array}$} & $\begin{array}{l}\text { With intact } \\
\text { skin }\end{array}$ & $60(31.41 \%)$ \\
\hline & $\begin{array}{l}\text { Skinless } \\
\text { chicken }\end{array}$ & $131(68.59 \%)$ \\
\hline \multirow{3}{*}{$\begin{array}{l}\text { What kind of slaughtered chicken } \\
\text { do you usually prefer? }\end{array}$} & Non-Halal & $15(8.06 \%)$ \\
\hline & $\begin{array}{l}\text { Any of the } \\
\text { above }\end{array}$ & $85(45.70 \%)$ \\
\hline & Halal only & $86(46.24 \%)$ \\
\hline $\begin{array}{l}\text { Would you prefer buying ready-to- } \\
\text { eat meat products in chicken/ meat } \\
\text { shop? }\end{array}$ & $\begin{array}{l}\text { No } \\
\text { Yes }\end{array}$ & $\begin{array}{l}131(67.88 \%) \\
62(32.12 \%)\end{array}$ \\
\hline
\end{tabular}

Value added processed meat products increase expediency to consumers by diminishing preparation time and curtailing processing steps. They are apprehending their share in the market. The growth of value-added processed meat products in the country is promising and is providing a massive opportunity for entrepreneurship progress (Kondaiah, 2004). Although, we are producing 
huge quantity of meat only just $3 \%$ of meat is laid open to processing. Along with this street food vending has become a frightening public health question and various studies have identified oodles of disease-causing organisms in street foods. Surprisingly, about $67.88 \%$ consumers were not interested to buy ready to eat meat products from meat shops. This could be due to inexperience about processed food available in the market. Similar finding was reported from Bangalore city where the majority of consumers unaware to processed food (Kiran et al., 2018).

\section{Hygienic consideration and expectation of consumers}

With the advancement of in acquaintance about the food they consume, the consumers have become more cautious regarding the quality and health aspects of foods (Selvan et al., 2007). A direct link between acquaintance about food safety and lifestyle has been studied by scholars (Abdullahi et al., 2016) Recent studies specified that consumers are concerned about the safety of non-veg food, but they have poor ability to differentiate meat (Li, 2012; Liang et al., 2014). The data regarding hygienic considerations and expectation of consumers depicted in Table 3.

Table 3: Hygienic considerations

\begin{tabular}{|c|c|c|}
\hline Question & Options & Result \\
\hline \multirow{2}{*}{$\begin{array}{l}\text { Would you prefer buying machine cut } \\
\text { meat being minimally handled? }\end{array}$} & No & $34(17.62 \%)$ \\
\hline & Yes & $159(82.38 \%)$ \\
\hline \multirow{2}{*}{$\begin{array}{l}\text { Would you prefer to buy neatly } \\
\text { packaged non veg product delivered to } \\
\text { your house? }\end{array}$} & No & $64(33.16 \%)$ \\
\hline & Yes & $129(66.84 \%)$ \\
\hline \multirow{2}{*}{$\begin{array}{l}\text { Would you prefer to buy hygienic \& } \\
\text { safe meat at slightly higher price than } \\
\text { that of local market? }\end{array}$} & No & $26(13.83 \%)$ \\
\hline & Yes & $162(86.17 \%)$ \\
\hline \multirow{3}{*}{$\begin{array}{l}\text { Are you aware of the fact that FSSAI } \\
\text { recommends storage of chicken/mutton } \\
\text { for three days at 4-degree Celsius } \\
\text { temperature? }\end{array}$} & Know & $123(63.73 \%)$ \\
\hline & Don't & $70(36.27 \%)$ \\
\hline & Know & \\
\hline \multirow{2}{*}{$\begin{array}{l}\text { Has anyone so far explained to you the } \\
\text { quality guidelines for chicken/mutton? }\end{array}$} & No & $88(45.60 \%)$ \\
\hline & Yes & $105(54.40 \%)$ \\
\hline \multirow{2}{*}{$\begin{array}{l}\text { Do you feel it's necessary to raise } \\
\text { awareness about quality, hygiene \& } \\
\text { safety standards for meat? }\end{array}$} & Agree & $187(96.89 \%)$ \\
\hline & Disagree & $6(3.11 \%)$ \\
\hline
\end{tabular}

From the obtained data it is revealed that about $82.38 \%$ consumers show their interest to buy minimally handle machine cut hygienic meat. They also showed willingness to purchase home delivery of neatly packaged non-veg product home delivered $(66.84 \%)$. The current finding showed consumers $(86.17 \%)$ are ready to pay a slightly higher price for hygienic, clean non-veg products. About $36.27 \%$ of the consumers were unaware about safe storage of meat and meat products for more than three days, which restrict the sale and consumption of frozen or chilled packaged meat products. This could be due to $45.60 \%$ consumers were unaware of the quality guiding principle for chicken or mutton. On the query regarding inevitability to raise awareness, almost all consumers $(96.89 \%)$ were agreeing on the need to spread knowledge and awareness about quality, hygienic production and safety standards for meat.

\section{CONCLUSION}

The present study revealed that most of the Maharashtrian consumers prefer chicken meat followed by mutton and other type of non-veg. From the findings of the study it can be concluded that maximum number of consumers purchased non-vegetarian foods one to two times in a week and they usually preferred freshly slaughtered meat processed in front of their eyes from same shop which is located near to their residence, where they had trust and ensure meat quality. Nonetheless, they showed their willingness to buy home delivery of machine cut, hygienic meat and they are ready to pay a slightly higher price for this. More than half percent consumers preferred to buy skinless chicken, which could be benefiting the meat processor, because scalder, defeathering machine will not require hence, an initial investment of the meat processor will be low. It can be also concluded that consumers are concerned about the safety of non-veg food, but maximum people were uninformed of the food laws and food safety, hence, there is a great necessity to educate consumers concerning issues related to meat quality and hygiene through trainings and awareness programs.

\section{ACKNOWLEDGMENTS}

Author acknowledge financial support for carrying out this study under DST-SSTP Project entitled "Dissemination of poultry and goat meat processing technology and establishment of meat processing demonstration unit for livelihood upliftment of farmers and butcher communities 
of Marathwada Region, Maharashtra" (Project No DST/ SSTP/2018-19/30 (G and C)).

\section{REFERENCES}

Abdullahi, A., Hassan, A., Kadarman, N., Saleh, A., Baraya, Y.U.S.A. and Lua, P.L. 2016. Food safety knowledge, attitude, and practice toward compliance with abattoir laws among the abattoir workers in Malaysia. Int. J. Gen. Med., 9: 79-87.

Anonymous, 2018. "Indians love meat of all kinds: That's what an RGI survey says". The Indian Express. Retrieved 23 July 2018.

Census of India. 2011. "Population of Maharashtra 2011 census". Press Population. Archived from the original on 2 February 2014.

Central Statistical Organization (2018). National Accounts Statistics, Department of Statistics, Ministry of Planning and Implementation, Government of India, New Delhi.

Food Safety and Standard Authority of India. Gazette of India: Extraordinary, Part-III Sec 4, p.374- 2.5. Retrieved on July 28 2016 from fssai website http://ww.fssai.gov.in/

GOI, MOHUA 2020, 'Level of Urbanisation' 23, October 2020.

Gossard, H. M. and York, R. 2003. Social structural influences on meat consumption. Hum. Ecol. Rev., 10(1): 1-9.

Government of India (GOI). 2019. 20 $0^{\text {th }}$ livestock census -2019 Al India report. Ministry of Fisheries, Animal Husbandry and Dairying. Department of Animal Husbandry, Dairying Animal Husbandry Statistics division, Krishi Bhavan, New Delhi.

Jaganmohan, M. 2020. Production volume of poultry meat in Maharashtra from financial year 2008 to 2017. Statista. May 28, 2020.

Karthikeyan, R. and Nedunchezhian, V.R. 2013. Vertical integration paving way to organised retailing in Indian poultry industry. Int. J. Bus. Manag. Invent. 2(1): 39-46.

Kiran, M., Naveena, B.M., Sudhakar Reddy, K., Kondal Reddy, K. and Madhav Rao, T. 2014. Effect of ammonium hydroxide on textural and ultra structural properties of spent hen meat. Int. Food Res. J., 21(5): 2049-2054.
Kiran, M., Nithin Prabhu, K., Paramesha, S.C., Rajshekar, T., Praveen, M.P., Punitkumar, C., Puneetha, S.C., Kumar, R., Rahul, Y. and Nagabhushan, C. 2018. Consumption pattern, consumer attitude and consumer perception on meat quality and safety in Southern India. Int. Food Res., J. 25(3): 10261030.

Kondaiah, N. 2004. Value added meat products and development of processed meat sector. Nat. Prod. Rad., 3(4): 281-83.

Kumar, N. and Kapoor, S. 2014. Study of consumers' behavior for non-vegetarian products in emerging market of India. $J$. Agribus. Dev. Emerg. Econ. 4 (1) 59-77.

Li, F. 2012. A study on behavior of consumer's purchase quality safety beef - based on the survey in Jilin province (Master's thesis). Retrieved on March 27 2016: http://www.cnki.net/ $\mathrm{KCMS} /$ detail/detail.aspx ? QueryID $=4 \&$ CurRec $=1 \&$ recid $=\&$ filename $=10131267$ 99.nh $\&$ dbname $=$ CMFD201301\&dbcod $\mathrm{e}=\mathrm{CMFD} \& \mathrm{pr}=\& u r l i d=\& \mathrm{yx}=\& \mathrm{v}=0 \mathrm{NjRSTCtmWWVkbUZ5}$ MjQemtWcjNNVkYyNkhiSzZ.

Liang, D., Li, T. and Gai, L. 2014. Characteristics and influencing factors of rural resident's beef consumption. Food Nutr. China 20 (5): 50-52.

Mohana, D.S., Balachandar, V. Lee, S.I. and Kim, I.H. 2014. An Outline of Meat Consumption in the Indian Population - A Pilot Review. Korean J. Food Sci. An., 34(4) 507-515.

Mullen, K., Williams, R. and Hunt, K. 2000. Irish descent, religion and food consumption in the west of Scotland. Appetite, 34(1): 47-54.

Pettinger, C., Holdsworth, M. and Gerber, M. 2004. Psychosocial influences on food choice in Southern France and Central England. Appetite, 42(3): 307-316.

Selvan, P., Narendra, B., Sureshkumar, S. and Venkatamanujam, V. 2007. Microbial quality of retail meat products available in Chennai city. Am. J. Food Technol., 2(1): 55-59.

Singh, S., Mehta, N., Kumar, M. Chatli and Malav, O.P. 2019. Consumer Studies on Meat Consumption and Processing Pattern through Contact Survey in Different Zones of Ludhiana City. J. of Ani. Res., 9(4) 605-611.

Verbeke, W. 2001. Beliefs, attitude and behaviour towards fresh meat revisited after the Belgian dioxin crisis. Food Qual. Prefer., 12(8): 489-98.

Wangdi, S. 2019. Challenges Consumer Face in Selecting Quality Meat. Magzeter. Retrieved May, 2019. 
